\title{
Metabolism of Basque streams measured with incubation chambers
}

\author{
Lide Aristegi, Oihana Izagirre and Arturo Elosegi*
}

Faculty of Science and Technology, University of the Basque Country, PO Box 644, 48080 Bilbao, Spain

* Corresponding author: arturo.elosegi@ehu.es

Received: 5/10/10 Accepted: 28/4/10

\begin{abstract}
Metabolism of Basque streams measured with incubation chambers

The metabolism (gross primary production, GPP; respiration, R; and net metabolism, NM) of epilithon was measured by incubating randomly selected cobbles in recirculatory chambers in 21 Basque streams running to the Atlantic coast. The studied streams spanned a broad range of environmental conditions and ranged in ecological status from excellent to poor. The GPP ranged from negligible to $35 \mathrm{~g} \mathrm{O}_{2} \mathrm{~m}^{-2} \mathrm{~d}^{-1}$, and the $\mathrm{R}$ ranged from 1 to $17 \mathrm{~g} \mathrm{O}_{2} \mathrm{~m}^{-2} \mathrm{~d}^{-1}$. The NM showed that the epilithon was autotrophic in 15 sites and heterotrophic in the rest. None of the measured environmental variables was significantly correlated with R. Stepwise analyses showed that both the GPP and the NM were related to the epilithic chlorophyll $a$ and phosphate concentrations. The metabolism values obtained were lower than those previously published from open-channel method, the number of autotrophic sites higher, and the controlling environmental variables different. The difference between open-channel and chamber methods was not related to the area covered with cobbles in the study sites. Although chamber measurements yield results in sites where open-channel methods do not work, they seem to overestimate the importance of autotrophy.
\end{abstract}

Key words: Stream, metabolism, epilithon, Spain.

\section{RESUMEN}

\section{Metabolismo de los ríos vascos medido con cámaras de incubación}

Se midió el metabolismo (producción primaria bruta, PPB; respiración, $R$; y metabolismo neto, MN) del epiliton en 21 ríos vascos que drenan a la costa atlántica, incubando cantos en cámaras recirculatorias. Los ríos estudiados comprendían un amplio abanico de condiciones ambientales y su estado ecológico iba desde excelente hasta pésimo. Los valores de PPB iban desde cercanos a 0 hasta $35 \mathrm{~g} \mathrm{O}_{2} \mathrm{~m}^{-2} \mathrm{~d}^{-1}$, los de R desde 1 hasta $17 \mathrm{~g} \mathrm{O}_{2} \mathrm{~m}^{-2} \mathrm{~d}^{-1}$. El MN indicaba que el epiliton de 15 ríos era autótrofo, el resto heterótrofo. Ninguna de las variables ambientales medidas estaba correlacionada de forma significativa con la R. Regresiones paso a paso indicaban que tanto la PPB como el MN estaban relacionados con la clorofila epilítica y con la concentración de fosfato. Los valores de metabolismo obtenidos fueron más bajos que los publicados previamente en base a métodos de cauce abierto, el número de tramos autotróficos era mayor, y las variables ambientales responsables diferentes. Las diferencias entre ambos métodos no eran proporcionales a la abundancia de cantos en el lecho. Auque las medidas en cámara permiten obtener resultados en tramos en los que no funcionan los métodos en cauce abierto, aparentemente sobreestiman la importancia de la autotrofia.

Palabras clave: Río, metabolismo, epiliton, España.

\section{INTRODUCTION}

The stream metabolism is an integrative measurement of ecosystem functioning, and thus, can po- tentially be used as a functional indicator of the ecological status of stream ecosystems (Young et al., 2006; Fellows et al., 2006). Its main components, gross primary production (GPP) and res- 
piration (R), are affected by factors such as nutrients, turbidity, canopy cover and temperature (Acuña et al., 2004; Young et al. 2004; Izagirre et al. 2008), and therefore, they respond to many human activities occurring in the basin.

The stream metabolism can be measured at the scale of individual substrata (typically cobbles) in closed chambers (Bott et al. 1996; Bunn \& Davies, 2000; Uehlinger et al. 2002) or at a reach scale by measuring diel changes in oxygen concentration on open channels (Marzolf et al. 1994; Mulholland et al., 2001; Bott et al., 2006). The open-channel approach critically depends on estimating the diffusion of oxygen between water and air, and the methods developed for that purpose often yield contrasting results (Generaux \& Hemond, 1992; Young \& Huryn, 1999; Aristegi et al., 2009). Nevertheless, these methods can be adapted to use data from continuous monitoring of water quality, and thus, they offer the possibility to monitor the ecosystem functioning almost in real time (Izagirre et al., 2007). The main drawback of the open-channel approach is that it cannot be used in situations where the oxygen saturation shows no diel changes, such as in steep mountain brooks, in highly shaded streams, or during floods. In addition, the chamber and open channel methods measure different parameters. The chamber method measures the metabolism of an enclosed community (e.g., epilithon), whereas the open-channel methods measure the ecosystem metabolism of an area that can be several km long (Reichert et al. 2009). Therefore, although the driving factors might not vary, the chamber and open-channel estimations are expected to differ. However, it is possible to obtain a better agreement between chamber and reach-scale estimations in areas dominated by the type of substrate analysed in chambers.

Despite its importance, metabolism has been relatively little studied in Iberian streams, and most research has focused on its seasonal variations in few study areas (e.g., Guasch \& Sabater, 1994; Mollá, 1996; Velasco et al., 2003; Acuña et $a l ., 2004)$. Therefore, we are still far from getting an accurate picture of the spatial and temporal variations of metabolism and of the factors governing these variations in Iberian streams. The
Iberian Peninsula features a large variety of climatic and geomorphic zones, which can have profound implications for the structure and functioning of stream ecosystems (e.g., Sabater et al., 2008). Recently, by applying the open-channel approach to data from multiple continuousmonitoring stations, Izagirre et al. (2008) studied the factors controlling the metabolism of Basque streams across a large range of environmental situations. Nevertheless, the absence of diel variations in oxygen concentration made it unfeasible to measure the whole stream metabolism of some areas.

Here, we present the results of epilithic metabolism measured with chambers in the same areas analysed in the Izagirre et al. (2008) study. In addition, we compare our results with those obtained with the open-channel method by Aristegi et al. (2009). The objectives of our study are 1) to get metabolism data of Basque streams at sites where the open-channel method could not be used, 2) to test the hypothesis that differences between epilithic and ecosystem metabolism are smaller in areas dominated by cobbles and boulders, and 3) to assess whether epilithic and whole-stream metabolism are controlled by the same environmental variables.

\section{METHODS}

This study was conducted in July of 2005 in the provinces of Biscay and Guipuscoa (Basque Country, northern Spain). The climate is humidoceanic, the average annual rainfall ranges from 1500 to $2500 \mathrm{~mm}$, and the average monthly temperatures range from $8^{\circ} \mathrm{C}$ to $19^{\circ} \mathrm{C}$. The area is hilly, with its lithology dominated by limestone, sandstone, and marl. Mountains of up to 1,500 masl are close to the sea, resulting in narrow, steep valleys, with streams that are short and steep. About 1.8 million people live in the industrialised areas of these provinces. Most rural areas are covered by intensively managed tree plantations of Monterey pine (Pinus radiata D. Don) and blue gum (Eucalyptus globulus Labill) harvested in short rotations with heavy machinery. Because of all these activities in such a small territory, most streams were severely polluted 


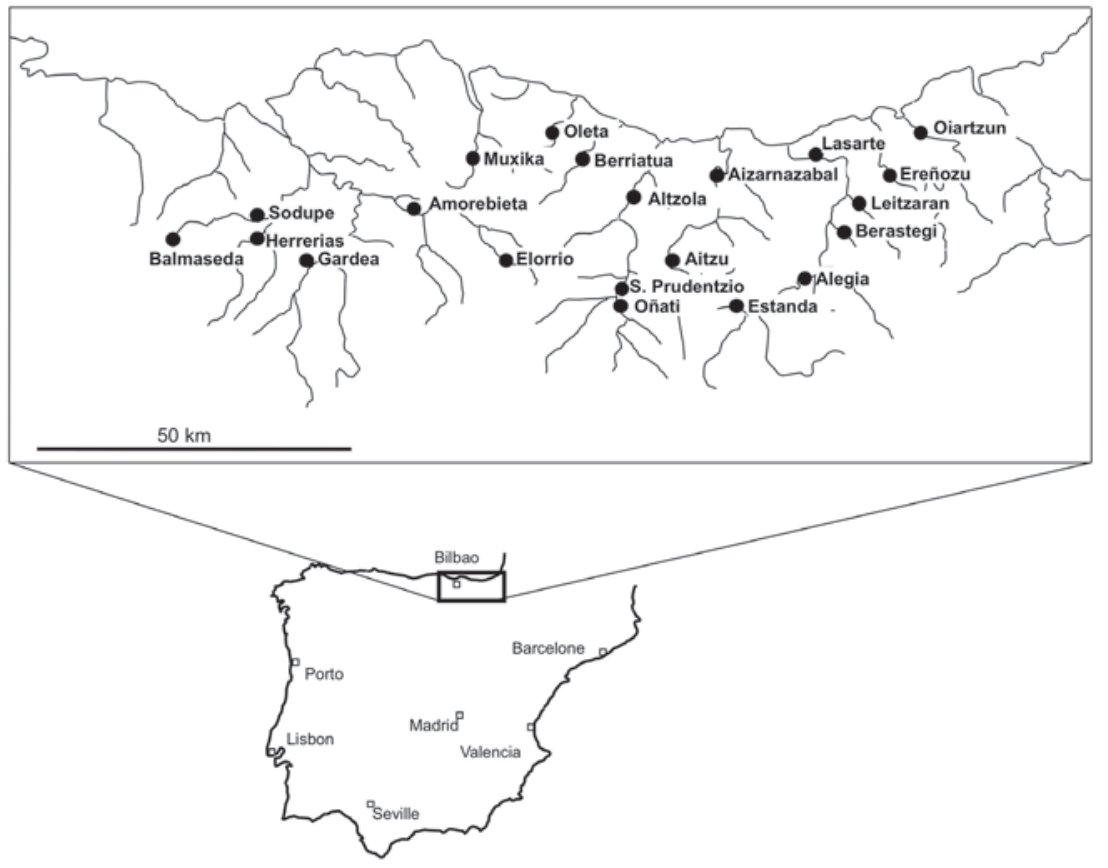

Figure 1. The study sites. Área de estudio.

by the mid- $20^{\text {th }}$ century. However, over the last 20 years, the water quality has been improving steadily (Arluziaga, 2002). Today, some streams are still severely degraded, whereas others have recovered enough to maintain salmon populations (Galera \& Antón, 2001). Apart from the chemical pollution, many Basque streams were canalised and have degraded margins and floodplains (Basque Government 2003).

Twenty-one stream areas (Fig. 1) with contrasting environmental conditions were studied. The catchment areas ranged from 2981 to 78677 ha, the average discharge ranged from 30 to $4800 \mathrm{l} / \mathrm{s}$, the channel width ranged from 9 to $46 \mathrm{~m}$, the canopy cover ranged from 0 to $70 \%$, and the ecological quality ranged from excellent to very poor (Table 1$)$. These are the same areas where Izagirre et al. (2008) measured the openchannel metabolism continuously for more than one year and where Aristegi et al. (2009) compared methods for measuring the re-aeration rate.

The epilithic metabolism was measured in the central hours of the day by means of six perspex chambers $(20 \times 30 \times 15 \mathrm{~cm})$ where water was kept in motion by water pumps (Maxi Jet 750) for two hours. A randomly selected cobble was enclosed in each chamber, the chambers were submerged in water, and three of them were covered with black opaque plastic. The oxygen was measured with an oxymeter WTW Oxi315i/SET at the onset of the experiment, after an hour and after two hours through a hole in the lid of each chamber that was otherwise kept closed with a screwed cap. After the incubation, we measured the volume (using a bucket and a beaker) and the area (by covering the cobble with aluminium foil, which was later weighed in the laboratory) of the cobble. The oxygen data from dark chambers were used to calculate the $\mathrm{R}$, the oxygen balance in light chambers to calculate the net metabolism (NM), and the sum of both to calculate the GPP of epilithon (all in $\mathrm{g} \mathrm{O}_{2} \mathrm{~m}^{-2} \mathrm{~h}^{-1}$ ). To allow for comparisons, these data were converted to daily metabolism. The daily $\mathrm{R}\left(\mathrm{g} \mathrm{O}_{2} \mathrm{~m}^{-2} \mathrm{~d}^{-1}\right)$ was calculated by multiplying the hourly respiration by 24 ; the daily GPP was calculated by multiplying the hourly NM by the number of daylight hours and adding R multiplied by daylight hours; 
Table 1. Environmental characteristics of the studied areas (Izagirre et al., 2008). The biotic index was calculated by the Basque Government (2003) with the invertebrate based Iberian Biological Monitoring Working Party (IBMWP) method (Alba-Tercedor \& Sanchez-Ortega 1988). Características ambientales de los tramos estudiados (Izagirre et al., 2008). El índice biótico fue calculado por el Gobierno Vasco (2003) mediante el método Iberian Biological Monitoring Working Party (IBMWP, Alba-Tercedor \& SanchezOrtega 1988), basado en invertebrados.

\begin{tabular}{lcccccc}
\hline Site & $\begin{array}{c}\text { Drainage } \\
\text { area (ha) }\end{array}$ & $\begin{array}{c}\text { Q } \\
\left(\mathrm{m}^{3} \mathrm{~s}^{-1}\right)\end{array}$ & $\begin{array}{c}\text { Width } \\
(\mathrm{m})\end{array}$ & $\begin{array}{c}\text { Depth } \\
(\mathrm{m})\end{array}$ & $\begin{array}{c}\text { Water velocity } \\
\left(\mathrm{m} \mathrm{s}^{-1}\right)\end{array}$ & $\begin{array}{c}\text { Canopy } \\
\text { cover }(\%)\end{array}$ \\
\hline Aitzu & 5973 & 0.10 & 12.9 & 0.27 & 0.33 & 20.3 \\
Aizarnazabal & 26896 & 1.61 & 22.7 & 1.34 & 0.30 & 51.4 \\
Alegia & 32974 & 0.92 & 36.2 & 1.34 & 0.26 & 14.9 \\
Altzola & 46254 & 1.28 & 31.1 & 0.51 & 0.24 & 12.3 \\
Amorebieta & 23718 & 0.93 & 23.3 & 0.45 & 0.23 & 0.0 \\
Balmaseda & 19576 & 1.33 & 23.9 & 0.23 & 1.54 & 20.9 \\
Berastegi & 2866 & 0.36 & 12.2 & 0.49 & 0.55 & 14.5 \\
Berriatua & 9281 & 0.17 & 18.7 & 0.24 & 0.30 & 31.7 \\
Elorrio & 2936 & 0.03 & 8.8 & 0.39 & 0.27 & 39.2 \\
Ereñozu & 21550 & 1.71 & 15.8 & 0.77 & - & 18.2 \\
Estanda & 5469 & 0.11 & 24.0 & 0.30 & 0.26 & 21.9 \\
Gardea & 32974 & 0.13 & 19.0 & 0.13 & 0.12 & 0.0 \\
Herrerias & 25436 & 0.07 & 26.6 & 0.18 & 0.34 & 3.4 \\
Lasarte & 78677 & 4.79 & 46.4 & 0.39 & 0.66 & 1.1 \\
Leitzaran & 11449 & 0.77 & 22.2 & 0.46 & 0.16 & 19.6 \\
Muxika & 3141 & 0.09 & 9.5 & 0.42 & 0.21 & 69.8 \\
Oiartzun & 5613 & 0.28 & 22.0 & 0.57 & 0.25 & 34.5 \\
Oleta & 6742 & 0.14 & 14.4 & 0.23 & 0.32 & 48.1 \\
Oñati & 9929 & 0.26 & 14.5 & 0.38 & 0.29 & 35.1 \\
S. Prudentzio & 12180 & 0.32 & 14.0 & 0.46 & 0.24 & 24.0 \\
Sodupe & 27680 & 0.71 & 30.0 & 2.14 & 0.57 & 0.0 \\
\hline
\end{tabular}

and the daily NM was calculated as the difference between the daily GPP and the daily R.

The photosynthetically active radiation (PAR) reaching the water surface was measured during the incubations every $15 \mathrm{~min}$ with a sensor LI-COR LI-240SA. After the incubations, the epilithon was sampled from the incubated cobbles. All the epilithic material was scraped from an area of $18.85 \mathrm{~cm}^{2}$ per stone using scalpels, toothbrushes and Pasteur pipettes. The samples were stored in plastic containers, enclosed in an ice box, and carried to the laboratory where they were frozen $\left(-20^{\circ} \mathrm{C}\right)$. Later, the samples were thawed and homogenised with a domestic blender. One subsample was used to determine the ash-free dry mass (AFDM) by drying it at $105^{\circ} \mathrm{C}$ for $24 \mathrm{~h}$ and ashing at $500^{\circ} \mathrm{C}$ for $4 \mathrm{~h}$. Another subsample was used to measure the epilithic chlorophyll $a$ content spectropho- tometrically after extraction in hot ethanol (Sartory \& Grobbelaar, 1984).

In addition, water samples for chemical analyses were also collected from the stream. All these samples were taken to the laboratory in an ice box and frozen until the analyses $\left(-20^{\circ} \mathrm{C}\right)$. Later, the samples were thawed and filtered (Whatman $\mathrm{GF} / \mathrm{C}$ ), and their nutrient were analysed. Nitrate, nitrite, ammonium and silicate in water were measured with TRAACS 800 auto analyser. Phosphate was measured by the stannous chloride method (APHA, 1992) on a Shimadzu UV-1603 spectrophotometer.

The water temperature, $\mathrm{pH}(\mathrm{pH}$ meter Hanna HI 9025), oxygen concentration (oxymeter WTW OXI 96), and conductivity (conductimeter WTW LF 90) were measured in the stream at the onset of the incubations. The characteristics of the area (width, depth, water velocity, substrate and riparian cover) were obtained from 10 cross- 
transects evenly spaced along an area five times longer than channel width (Izagirre et al. 2008).

To discern the environmental variables controlling the epilithon, Pearson correlations were performed with epilithic biomass and chlorophyll (log-transformed for normality) as dependent variables and environmental variables as independent ones. To test the hypothesis that differences between epilithic and ecosystem metabolism are smaller in areas dominated by similar rock material, where communities other than epilithic are rare, we computed the standardised difference between chamber and openchannel methods, comparing our results to those simultaneously measured by the open-channel method by Aristegi et al. (2009). The standardised difference was calculated as the absolute value of the metabolism (either R, GPP or NM) calculated by the open method minus the metabolism calculated in chambers divided by the metabolism calculated by the open method. Furthermore, we performed linear regressions with cover of rock material (cobbles, cobbles + boulders, cobbles + boulders + rocks) as the independent variables and the standardised difference in R, GPP, and NM estimations as the dependent ones. Finally, to determine the environmental variables controlling the metabolism, we performed stepwise regressions with epilithic metabolism (R, GPP and NP) as dependent variables and 12 independent variables: benthic AFDM, chlorophyll $a$, incident PAR, nitrate, nitrite, ammonium, phosphate and silicate concentrations, discharge, width, depth, and riparian cover. All the statistical analyses were performed with Statview 5.0.1 for Macintosh.

Table 2. Characteristics of the stream water and photosynthetically active radiation (PAR) during the metabolism incubations. b.d.l. = below detection level. The PAR was measured every 15 minutes, and the rest of the variables were measured once, at the onset of incubation. Características del agua y radiación fotosintéticamente activa $(P A R)$ durante las incubaciones de metabolismo. b.d.l. $=$ por debajo del nivel de detección. El PAR se midió cada 15 minutos, el resto de las variables una vez, al inicio de la incubación.

\begin{tabular}{|c|c|c|c|c|c|c|c|c|c|c|}
\hline Site & $\begin{array}{c}\text { Temperature } \\
\left({ }^{\circ} \mathrm{C}\right)\end{array}$ & $\mathrm{pH}$ & $\begin{array}{l}\text { Conductivity } \\
\left(\mu \mathrm{S} \mathrm{cm}^{-1}\right)\end{array}$ & $\begin{array}{c}\text { Oxygen } \\
(\%)\end{array}$ & $\begin{array}{l}\text { Nitrate } \\
(\mu \mathrm{g} N / \mathrm{l})\end{array}$ & $\begin{array}{l}\text { Nitrite } \\
(\mu \mathrm{g} N / \mathrm{l})\end{array}$ & $\begin{array}{c}\text { Ammonium } \\
(\mu \mathrm{g} N / \mathrm{l})\end{array}$ & $\begin{array}{c}\text { Phosphate } \\
(\mu \mathrm{g} \mathrm{P} / \mathrm{l})\end{array}$ & $\begin{array}{l}\text { Silicate } \\
(\mu \mathrm{g} \mathrm{Si} / \mathrm{l})\end{array}$ & $\begin{array}{c}\text { PAR } \\
\left(\mu \mathrm{E} \mathrm{m}^{-2} \mathrm{~s}^{-1}\right)\end{array}$ \\
\hline Aitzu & 22.5 & 8.15 & - & 125.8 & b.d.l. & 75 & 816 & 969 & 2308 & 1134 \\
\hline Aizarnazabal & 17.8 & 7.90 & 479 & 99.7 & 151 & 23 & 78 & 24 & 444 & 628 \\
\hline Alegia & 22.1 & 7.24 & 591 & 76.8 & 871 & 78 & 72 & 107 & 1239 & 214 \\
\hline Altzola & 21.5 & 7.59 & 753 & 86.4 & 116 & 32 & 393 & 237 & 4243 & 1763 \\
\hline Amorebieta & 22.1 & 7.79 & 587 & 101.0 & 1022 & 37 & 82 & 149 & 846 & 1197 \\
\hline Balmaseda & 17.9 & 8.04 & 620 & 136.0 & 1319 & 72 & 76 & 95 & 1756 & 1758 \\
\hline Berastegi & 19.1 & 7.48 & 1039 & 86.5 & 1607 & 110 & 89 & 122 & 980 & 996 \\
\hline Berriatua & 19.5 & 7.75 & 410 & 94.1 & 1816 & 393 & 1795 & 134 & 2649 & 52 \\
\hline Elorrio & 19.1 & 7.94 & 548 & 82.5 & 36 & 16 & 99 & 212 & 689 & 706 \\
\hline Ereñozu & 18.9 & 7.85 & 134 & 99.9 & 1268 & 124 & 77 & 85 & 347 & 1699 \\
\hline Estanda & 18.0 & 7.92 & 764 & 75.8 & 1661 & 29 & 140 & 72 & 1014 & 366 \\
\hline Gardea & 18.9 & 8.45 & 4964 & 107.5 & 101 & 23 & 68 & 99 & 1343 & 1218 \\
\hline Herrerías & 29.2 & 8.71 & 355 & 167.2 & 1997 & 205 & 99 & 343 & 433 & 787 \\
\hline Lasarte & 19.5 & 7.13 & 546 & 96.7 & 1907 & 172 & 125 & 24 & 330 & 717 \\
\hline Leitzaran & 18.1 & 7.50 & 216 & 97.3 & 2663 & 245 & 131 & 401 & 471 & 743 \\
\hline Muxika & 18.5 & 7.78 & 417 & 89.4 & 2021 & 38 & 197 & 51 & 1682 & 282 \\
\hline Oiartzun & 16.4 & 7.79 & 259 & 98.8 & 15 & 15 & 79 & 807 & 1876 & 864 \\
\hline Oleta & 19.0 & 7.36 & 359 & 91.4 & 974 & 91 & 196 & 95 & 1562 & 1382 \\
\hline Oñati & 25.1 & 8.24 & 314 & 208.0 & 951 & 51 & 96 & 74 & 541 & 1037 \\
\hline S. Prudentzio & 21.1 & - & - & 11.7 & 2021 & 38 & 197 & 51 & 1682 & 1366 \\
\hline Sodupe & 22.8 & - & - & 96.6 & 419 & 29 & 49 & 96 & 430 & 1405 \\
\hline
\end{tabular}




\section{RESULTS}

There were large differences in environmental characteristics, reflecting differences in catchments (Table 2). The water temperature ranged from 16.4 to $29.2^{\circ} \mathrm{C}$; the lowest value occurred at small streams with good riparian forests, while the highest, at larger streams with more stagnant waters. The $\mathrm{pH}$ was circumneutral in all the areas. The conductivity ranged from $134 \mu \mathrm{S} / \mathrm{cm}$ in Ereñozu, a clear water stream with siliceous catchment, to 4964 in Gardea, which is an area affected by an upstream salty diapir. The oxygen saturation ranged from $12 \%$ in the extremely polluted San Prudentzio to $208 \%$ in Oñati and reflected the balance between primary production and respiration. The concentration of nutrients changed in 1-2 orders of magnitude. The nitrate ranged from non detectable to over $2600 \mu \mathrm{g} \mathrm{N} / \mathrm{l}$, while the nitrite levels almost reached $400 \mu \mathrm{g} \mathrm{N} / \mathrm{l}$ and the ammonium, almost $1800 \mu \mathrm{g} \mathrm{N} / \mathrm{l}$. Overall, the inorganic nitrogen showed different re- dox states from waters dominated by reduced forms (e.g., Aitzu, located below a water treatment plant) to waters dominated by oxidised forms. The concentration of phosphate ranged from 24 to over $800 \mu \mathrm{g} \mathrm{P} / \mathrm{l}$, and the one of silicate, from 300 to over $4000 \mu \mathrm{g} \mathrm{Si} / \mathrm{l}$. The photosynthetically active radiation ranged from 52 to over $1700 \mu \mathrm{E} \mathrm{m}^{-2} \mathrm{~s}^{-1}$ showing the effects of both weather and riparian cover.

The epilithic biomass ranged (Table 3) from 7-8 g AFDM $/ \mathrm{m}^{2}$ (Aizarnazabal, Leitzaran) to $146 \mathrm{~g} \mathrm{AFDM} / \mathrm{m}^{2}$ (Oleta). The chlorophyll $a$ content ranged from $14.8 \mathrm{mg} / \mathrm{m}^{2}$ (Aizarnazabal) to $847.9 \mathrm{mg} / \mathrm{m}^{2}$ (Altzola). The epilithic communities were dominated by filamentous green algae, while diatoms and red algae were less abundant. In San Prudentzio, the cobbles were covered by thick Sphaerotilus mats. Pearson correlation between epilithic variables and environmental variables showed that the AFDM was highly correlated with chlorophyll $(r=0.706, p<0.01)$ and significantly correlated with PAR $(r=0.464$,

Table 3. Biomass, chlorophyll $a$, and metabolism of the epilithon in the incubated cobbles. $\mathrm{NM}=$ net metabolism; $\mathrm{R}=$ respiration; $\mathrm{GPP}=$ gross primary production. Average and standard deviation shown. There was no SD for GPP. Biomasa y clorofila a, y metabolismo del epiliton en los cantos incubados. $N M=$ metabolismo neto $R=$ respiración; $G P P=$ producción primaria bruta. Se proporcionan los datos medios y la desviación típica. No hay desviación típica para los datos de producción primaria bruta.

\begin{tabular}{lccccc}
\hline Site & $\begin{array}{c}\mathrm{AFDM}\left(\mathrm{g} \mathrm{m}^{-2}\right) \\
(\mathrm{n}=6)\end{array}$ & $\begin{array}{c}\left.\mathrm{Chl}(\mathrm{mg} \mathrm{m})^{-2}\right) \\
(\mathrm{n}=6)\end{array}$ & $\begin{array}{c}\mathrm{NM}\left(\mathrm{g} \mathrm{O}_{2} \mathrm{~m}^{-2} \mathrm{~d}^{-1}\right) \\
(\mathrm{n}=3)\end{array}$ & $\begin{array}{c}\mathrm{R}\left(\mathrm{g} \mathrm{O}_{2} \mathrm{~m}^{-2} \mathrm{~d}^{-1}\right) \\
(\mathrm{n}=3)\end{array}$ & $\begin{array}{c}\mathrm{GPP} \\
\left(\mathrm{g} \mathrm{O}_{2} \mathrm{~m}^{-2} \mathrm{~d}^{-1}\right)\end{array}$ \\
\hline Aitzu & $48.1 \pm 244.3$ & $110.9 \pm 110.9$ & $16.1 \pm 3.1$ & $11.8 \pm 8.7$ & 27.8 \\
Aizarnazabal & $7.2 \pm 213.8$ & $14.8 \pm 14.8$ & $-0.8 \pm 0.4$ & $2.7 \pm 0.5$ & 1.9 \\
Alegia & $28.9 \pm 21.9$ & $139.4 \pm 66.6$ & $1.1 \pm 0.4$ & $17.2 \pm 21.9$ & 18.3 \\
Altzola & $88.2 \pm 45.2$ & $847.9 \pm 86.0$ & $29.0 \pm 4.8$ & $6.3 \pm 2.3$ & 35.3 \\
Amorebieta & $41.8 \pm 11.3$ & $246.0 \pm 123.2$ & $7.3 \pm 3.5$ & $3.7 \pm 3.1$ & 10.9 \\
Balmaseda & $111.0 \pm 1015.9$ & $289.2 \pm 289.2$ & $-1.8 \pm 19.7$ & $10.2 \pm 3.5$ & 8.5 \\
Berastegi & $48.4 \pm 46.0$ & $125.0 \pm 104.5$ & $2.6 \pm 0.4$ & $3.0 \pm 2.2$ & 5.6 \\
Berriatua & $15.1 \pm 5.1$ & $48.2 \pm 20.8$ & $0.2 \pm 0.4$ & $3.9 \pm 1.2$ & 4.0 \\
Elorrio & $8.8 \pm 4.8$ & $62.4 \pm 64.6$ & $1.2 \pm 0.3$ & $10.0 \pm 7.7$ & 11.2 \\
Ereñozu & $8.9 \pm 3.5$ & $59.2 \pm 36.2$ & $2.1 \pm 1.8$ & $1.3 \pm 0.8$ & 3.3 \\
Estanda & $46.7 \pm 47.1$ & $271.0 \pm 293.4$ & $-3.3 \pm 1.5$ & $12.6 \pm 7.9$ & 9.3 \\
Gardea & $34.4 \pm 18.5$ & $238.4 \pm 220.2$ & $5.8 \pm 16.8$ & $3.7 \pm 0.4$ & 9.5 \\
Herrerias & $29.8 \pm 7.2$ & $81.4 \pm 29.7$ & $-0.3 \pm 15.1$ & $9.9 \pm 3.2$ & 9.7 \\
Lasarte & $16.3 \pm 9.6$ & $288.9 \pm 327.5$ & $-3.3 \pm 14.0$ & $8.8 \pm 0.7$ & 5.5 \\
Leitzaran & $7.9 \pm 54.7$ & $46.9 \pm 46.9$ & $3.1 \pm 1.3$ & $5.5 \pm 5.5$ & 8.6 \\
Muxika & $33.5 \pm 28.9$ & $37.1 \pm 10.3$ & $0.7 \pm 0.2$ & $1.1 \pm 0.2$ & 1.8 \\
Oiartzun & $13.6 \pm 4.6$ & $73.4 \pm 8.8$ & $3.5 \pm 1.3$ & $10.7 \pm 16.5$ & 14.2 \\
Oleta & $146.0 \pm 111.8$ & $277.4 \pm 254.5$ & $9.8 \pm 25.0$ & $5.6 \pm 7.4$ & 15.4 \\
Oñati & $39.6 \pm 14.9$ & $96.2 \pm 46.7$ & $4.2 \pm 0.0$ & $6.7 \pm 0.0$ & 10.9 \\
S.Prudentzio & $40.6 \pm 48.2$ & $39.4 \pm 35.9$ & $-8.7 \pm 4.9$ & $8.0 \pm 1.7$ & 0.0 \\
Sodupe & $91.9 \pm 26.0$ & $288.2 \pm 173.0$ & $11.7 \pm 1.1$ & $4.3 \pm 0.8$ & 16.0 \\
\hline
\end{tabular}


$p<0.05)$. In addition, chlorophyll $a$ showed a highly significant correlation $(p<0.01)$ with cover $(r=0.566)$ and significant correlations $(p<0.05)$ with PAR and channel width $(r=0.494$ and 0.458 , respectively).

The epilithic metabolism showed large differences between sites. The respiration varied from 1 to $17 \mathrm{~g} \mathrm{O}_{2} \mathrm{~m}^{-2} \mathrm{~d}^{-1}$, and the gross primary production ranged from 0 to $35 \mathrm{~g} \mathrm{O}_{2} \mathrm{~m}^{-2} \mathrm{~d}^{-1}$. As a result, the epilithon's net metabolism ranged from -8.7 to $29 \mathrm{~g} \mathrm{O}_{2} \mathrm{~m}^{-2} \mathrm{~d}^{-1}$, and it was autotrophic in 15 out of 21 areas during the measurements. Stepwise regressions between chamber metabolism (GPP, R and NP) and environmental variables showed no significant relationship for the epilithic respiration. In contrast, both GPP and NP were directly related to chlorophyll and phosphate, as described by the following models:

$$
\begin{aligned}
\mathrm{GPP}= & 0.0322 \mathrm{Chl} a+0.014 \mathrm{Phosp}-1.487 \\
& \left(r^{2}=0.673, p<0.0001\right) \\
\mathrm{NP}= & 0.0344 \mathrm{Chl} a+0.020 \mathrm{Phosp}+0.722 \\
& \left(r^{2}=0.890, p<0.0001\right)
\end{aligned}
$$

Contrary to our expectations, the standardised differences in metabolism between chamber and open-channel calculations were not related to the proportion of stream bed covered by cobbles (linear regression, $p \gg 0.05$ ). We only got a marginally significant relationship between the cover of particles larger than gravel (pebbles, cobbles, boulders and rocks) and the standardised differences in GPP $\left(r^{2}=0.196 ; p=0.099\right)$ and NM $\left(r^{2}=0.250 ; p=0.058\right)$. Nevertheless, in both cases the relationship was positive, i.e., the standardised difference between chamber and open-channel estimations increased with the area covered with hard sediments.

\section{DISCUSSION}

Our work presents, to our knowledge, the first dataset of chamber metabolism in multiple Iberian streams. Although restricted to a single ecoregion, the 21 studied sites included areas in all the major basins in Guipuscoa and Biscay, and they covered most environmental situations found in Basque Atlantic streams, with the exception of small headwater reaches. Basque Atlantic streams typically show little seasonality (Sabater et al., 2008) but large interannual variability derived from changing rainfall patterns (Izagirre \& Elosegi, 2005; Elosegi et al., 2006). Therefore, caution is necessary when comparing the present data with other results, even if they were obtained at the same streams. For instance, the epilithic biomass value of our study was much lower than the data already published for the same areas (Sabater et al., 2000; Izagirre et al., 2008). However, those data coincided with dry and hot summers, which are situations that promote the development of large algal mats (Mosisch \& Bunn, 1997), whereas our data corresponded to a rainy year, where both light availability and discharge would limit algal growth (Biggs, 2000).

Not only can the epilithic biomass be highly variable from year to year, but also the factors governing it can change in relation to environmental conditions, as has been described in the Agüera stream (Biscay). Elósegui \& Pozo (1998) reported that the spatial distribution of epilithic biomass mainly depended on light and nutrients, and that the temporal variations were controlled by floods. Similarly, Izagirre \& Elosegi (2005) showed that in open canopy areas, the seasonal variations in epilithic biomass were controlled by the stage of the river, whereas in closed canopy areas, the seasonality of irradiance was an important factor. In normal years, the epilithic biomass could be adequately modelled based on the river discharge, whereas in dry years, the number of environmental variables affecting the biomass is higher (Boulêtreau et al., 2008). In the present study, cover and irradiance seemed to be the main environmental variables controlling the spatial differences in epilithic biomass, whereas the role of nutrients seems to be negligible. The influence of light on epilithic biomass has been shown both observationally (Sabater et al., 2008) and experimentally (von Schiller et al., 2007), whereas the relationship between nutrients and epilithon is complex because algae are both dependent 
and controllers of nutrient concentrations as well as because the internal recycling of nutrients in biofilms is important (Mulholland, 1996).

Our metabolism results are in the same order of magnitude of previously published works on Iberian streams from chamber incubations (e.g., Mollá et al., 1996; Velasco et al., 2003). Our results are also similar to those obtained from openchannel methods in the summer of 2003 in the same areas (Izagirre et al., 2008), and therefore, they are useful to fill the gaps in that study, which occurred because the diel changes were too small at some sites or because of the malfunction of the oxygen electrode. Interestingly, according to the chamber data, the sites where the open-channel method failed were not because of the intensity of the metabolism, but the failure was related to the characteristics of the channel (turbulence, variable water quality).

By contrast, although the values of epilithic GPP and R seem to be similar to the ecosystem metabolism calculated by the open-channel method, they suggest an entirely different trophic balance. All ecosystems except one stream were heterotrophic during the summer of 2003, whereas the epilithic communities were autotrophic in 15 out of 21 sites in the summer of 2005. The chambers can limit the availability of nutrients and, thus, affect the primary production estimates, especially at oligotrophic sites (Bott $e t$ $a l$. 1997). Conversely, the underestimation of respiration likely results from the exclusion of macrofauna (Marzolf et al., 1994), and especially of hyporheos, which contributes to up to $70 \%$ of the ER (Naegeli \& Uehlinger, 1997; Fellows et al., 2001). Furthermore, the metabolic activity differs markedly between different stream compartments such as macrophytes, algal mats and fine sediments (Velasco et al., 2003) making it difficult to get a representative sampling.

When comparing our results with those obtained simultaneously by the open-channel method (Aristegi et al., 2009), the epilithic GPP values were below the whole ecosystem GPP in $82 \%$ of the occasions, and the epilithic R values in $91 \%$ of the occasions. As a result, $91 \%$ of the NM estimations in chambers were higher, more autotrophic than the open-channel estima- tions. As noted by Odum (1956), the diel oxygen curve gives accurate information on the autotrophic or heterotrophic characteristics of each area, even when the calculated GPP or R values are inaccurate. Thus, the metabolic chambers are less reliable than the open methods to measure stream trophic status. In our case, it seems that the exclusion of hyporheos was the main factor behind the overestimation of the NM. Indeed, many Basque streams still receive fairly large amounts of labile organic matter that results in a high biological oxygen demand in the sediments (Basque Government, 2003), which suggest that a large fraction of the ecosystem respiration is linked to the hyporheos. The differences between methods affected not only the results but also the environmental factors controlling the metabolism. When using the open channel method, the whole-ecosystem GPP was related to turbidity and catchment activities, not to the epilithic biomass (Izagirre et al., 2008), whereas the production in the chambers was related to the epilithic biomass and phosphate.

Thus, chamber and open-channel methods offer different pictures of stream metabolism, both in terms of spatial cover -some $\mathrm{cm}^{2}$ in the case of chambers up to several $\mathrm{km}^{2}$ in open channeland of the components involved. Stream ecosystems are spatially complex entities where substantial differences between patches are common (Elosegi et al. 2010). Therefore, to adequately reflect whole-stream metabolism, the chamber measurements should include a sufficient number of replicates of metabolically important components (Bott, 1996), which is rarely carried out. Instead, most chamber studies focus on which are considered the main drivers of ecosystem metabolism, such as the cobbles in our case. Indeed, because other producers, such as plankton or macrophytes, are rare in Basque streams, one might hypothesise a good agreement between GPP in chambers and in entire areas, but that was not the case in the present study. Furthermore, there was either no statistically significant relationship between the covered area of the studied substrate type (cobbles) and the standardised differences between chamber and openchannel measurements, or the trends run in op- 
posite directions, i.e., larger differences where stones (pebbles to rocks) were more abundant. All these findings suggest that the results from chamber incubations are highly limited in spatial scope and that extrapolating them, even in streams dominated by a single type of substrate, is highly risky.

\section{ACKNOWLEDGMENTS}

This research was funded by the Spanish Department of Science and Technology, the University of the Basque Country, and the European Regional Development Fund through projects 9/UPV00118.310-14476/2002 and BOS200304466. Oihana Izagirre took part in this work thanks to a pre-doctoral grant by the Basque Government.

\section{REFERENCES}

ACUÑA, V., A. GIORGI, I. MUÑOZ, U. UEHLINGER, \& S. SABATER. 2004. Flow extremes and benthic organic matter shape the metabolism of a headwater Mediterranean stream. Freshwat. Biol., 49: 960-971.

ALBA TERCEDOR, J. \& A. SÁNCHEZ ORTEGA. 1988. Un método rápido y simple para evaluar la calidad biológica de las aguas corrientes basado en la de Hellawell. Limnetica, 4: 51-56.

APHA (American Public Health Association). 1992. Standard methods for the examination of water and wastewater. 18th edition. American Public Health Association, Washington, D.C., USA. $1100 \mathrm{pp}$.

ARISTEGI, L., O. IZAGIRRE \& A. ELOSEGI. 2009. Comparison of several methods to calculate reareation in streams and their effects on metabolism estimations. Hydrobiologia, 635: 113124.

ARLUZIAGA, I. 2002. Variación de La calidad de las aguas de los ríos gipuzkoanos al cabo de veinte años (1981-2001). Munibe, 53: 39-56.

BASQUE GOVERNMENT. 2003. Red de vigilancia de las masas de agua superficial de la Comunidad Autónoma del País Vasco. Gobierno Vasco, Vitoria-Gasteiz, España. 2405 pp.

BIGGS, B. J. F. 2000. Eutrophication of streams and rivers: dissolved nutrient-chlorophyll relationships for benthic algae. J. N. Am. Benthol. Soc., 19: 1731.

BOTT, T. L. 1996. Primary productivity and community respiration. In: Methods in stream ecology. F. R. Hauer \& G. A Lamberti, (eds.): 533-556. Academic Press, San Diego, USA.

BOTT, T. L., D. S. MONTGOMERY, J. D. NEWBOLD, D. B. ARSCOTT, C. L. DOW, A. K. AUFDENKAMPE, J. K. JACKSON, \& L. A. KAPLAN. 2006. Ecosystem metabolism in streams of the Catskill Mountains (Delaware and Hudson River watersheds) and Lower Hudson Valley. J. N. Am. Benthol. Soc., 25: 1018-1044.

BOULÊTREAU, S., O. IZAGIRRE, F. GARABÉTIAN, S. SAUVAGE, A. ELOSEGI \& J. M. SÁNCHEZ PÉREZ. 2008. Identification of a minimal adequate model to describe the biomass dynamics of river epilithon. River Res. \& Appl., 24: 36-53.

BUNN, S. E. \& P. M. DAVIES. 2000. Biological processes in running waters and their implications for the assessment of ecological integrity. Hydrobiologia, 422/423: 61-70.

ELÓSEGUI, A. \& J. POZO. 1998. Epilithic biomass and metabolism in a north Iberian stream. Aquat. Sci., 60: 1-16.

ELOSEGI, A., A. BASAGUREN \& J. POZO . 2006. A functional approach to the ecology of Atlantic Basque streams. Limnetica, 25: 123-134.

ELOSEGI, A., J. R. DÍEZ, \& M. MUTZ. 2010. Effects of hydromorphological integrity on biodiversity and functioning of river ecosystems. Hydrobiologia, 657: 199-215.

FELLOWS, C. S., J. E. CLAPCOTT, J. W. UDY, S. E. BUNN, B. D. HARCH, M. J. SMITH, \& P. M. DAVIES. 2006. Benthic metabolism as an indicator of stream ecosystem health. Hydrobiologia, 572: 71-87.

GALERA, A. \& A. ANTÓN. 2001. Situación actual del salmón atlántico en Bizkaia. In: El salmón, joya de nuestros ríos. C. García de Leániz, A. Sedio \& S. Consuegra (eds.): 83-88. Gobierno de Cantabria, Consejería de Ganadería, Agricultura y Pesca, Santander.

GENEREUX, D. P. \& H. F. HEMOND. 1992. Determination of gas exchange rate constants for a small stream on Walker Branch watershed, Tennessee. Wat. Resour. Res., 28: 2365-2374.

GUASCH, H. \& S. SABATER. 1994. Primary production of epilithic communities in undisturbed 
Mediterranean streams. Verh. Internat. Verein. Limnol., 25: 1762-1764.

IZAGIRRE, O. \& A. ELOSEGI. 2005. Environmental control of seasonal and inter-annual variations of periphytic biomass in a north Iberian stream. Annl. Limnol., 41: 35-46.

IZAGIRRE, O., M. BERMEJO, J. POZO \& A. ELOSEGI. 2007. RIVERMETC): an Excel-based tool to calculate river metabolism from diel oxygen concentration curves. Environ. Mod. \& Soft., 22: 24-32.

IZAGIRRE, O., U. AGIRRE, M. BERMEJO, J. POZO \& A. ELOSEGI. 2008. Environmental controls of whole-stream metabolism as depicted from continuous monitoring of Basque streams. J. N. Am. Benthol. Soc., 27: 252-268.

MARZOLF, E. R., P. J. MULHOLLAND \& A. D. STEINMAN. 1994. Improvements to the diurnal upstream-downstream dissolved oxygen change technique for determining whole-stream metabolism in small streams. Can. J. Fish. Aquat. Sci., 51: 1591-1599.

MOLLÁ, S., L. MALTCHICK, C. CASADO \& C. MONTES. 1996. Particulate organic matter and ecosystem metabolism dynamics in a temporary Mediterranean stream. Arch. Hydrobiol., 137: 59-76.

MOSISCH, T. D. \& S. E. BUNN. 1997. Temporal patterns of rainforest stream epilithic algae in relation to flow-related disturbance. Aquat. Bot., 58: 181-193.

MULHOLLAND, P. J. 1996. Role in nutrient cycling in streams. In: Algal Ecology. R.J. Stevenson, M. L. Bothwell \& R. L. Lowe (eds.): 609-639. Academic Press, California.

MULHOLLAND, P. J., C. S. FELLOWS, J. L. TANK, N. B. GRIMM, J. R. WEBSTER, S. K. HAMILTON, E. MARTÍ, L. ASHKENAS, W. B. BOWDEN, W. K. DODDS, W. H. MCDOWELL, M. J. PAUL \& B. J. PETERSON. 2001. Interbiome comparison of factors controlling stream metabolism. Freshwat. Biol., 46: 1503-1517.

NAEGELI, M. W. \& U. UEHLINGER. 1997. Contribution of the hyporheic zone to ecosystem metabolism in a prealpine gravel-bed river. $J . N$. Am. Benthol. Soc., 16: 794-804.
ODUM, H. T. 1956. Primary production in flowing waters. Limnol. \& Oceanogr., 2: 85-97.

REICHERT, P., U. UEHLINGER, \& V. ACUÑA. 2009. Estimating stream metabolism from oxygen concentration: effect of spatial heterogeneity. $J$. Geophys. Res., 114. DOI: 10.1029/2008JG000917.

SABATER, S., J. ARMENGOL, E. COMÁS, F. SABATER, I. URRIZALQUI, \& J. URRUTIA. 2000. Algal biomass in a disturbed Atlantic river: water quality relationships and environmental implications. STOTEN, 263: 185-195.

SABATER, S., A. ELOSEGI, V. ACUÑA, A. BASAGUREN, I. MUÑOZ \& J. POZO. 2008. Effect of climate on the trophic structure of temperate forested streams. A comparison of Mediterranean and Atlantic streams. STOTEN, 390: 475-484.

SARTORY, D. P. \& J. E. GROBBELAAR. 1984. Extraction of chlorophyll $a$ from freshwater phytoplankton for spectrophotometric analysis. Hydrobiologia, 114: 177-187.

UEHLINGER U., M. W. NAEGELI \& S. G. FISHER. 2002. A heterotrophic desert stream? The role of sediment stability. W. N. Am. Natur., 62: 466-473.

VON SCHILLER, D., E. MARTÍ, J. L. RIERA \& F. SABATER. 2007. Effects of nutrients and light on periphyton biomass and nitrogen upake in Mediterranean streams with contrasting land uses. Freshwat. Biol., 52: 891-906.

VELASCO, J., M. MILLÁN, M. R. VIDAL-ABARCA, M. L. SUÁREZ, C. GUERRERO \& M. ORTEGA. 2003. Macrophytic, epipelic and epilithic primary production in a semiarid Mediterranean stream. Freshwat. Biol., 48: 1408-1420.

YOUNG, R. G. \& A. D. HURYN, 1999. Effects of land use on stream metabolism and organic matter turnover. Ecol. Appl., 9: 1359-1376.

YOUNG, R. G., C. R. TOWNSEND \& C. MATTHAEI. 2004. Functional indicators of river ecosystem health - an interim guide for use in New Zealand. Cawthron, Dunedin, New Zealand. Report No. 870.54 pp.

YOUNG, R. G., C. MATTHAEI \& C. R. TOWNSEND. 2006. Functional indicators of river ecosystem health. Final project report. Cawthron, Dunedin, New Zealand. Report No. 1174. 38pp. 